\title{
Research on College Students' Consumption Behavior of Jinjiang Sportswear Brand Based on Green Marketing
}

\author{
Qian Yang \\ Clothing and Design Faculty \\ Minjiang University \\ Fuzhou, China
}

\begin{abstract}
Jinjiang has become an industrial cluster for the development of China's sportswear brand, and its brand popularity and international influence are growing. The green marketing of Jinjiang sportswear brand is conducive to reducing the destruction of the natural environment and waste of natural resources, promoting the development of green economy, and promoting the harmonious development of human and nature. Through questionnaire survey, this paper uses SPSS software to analyze college students' consumption behavior of Jinjiang sportswear brand on environmental responsibility, consumption level and $4 \mathrm{P}$ of green marketing, and puts forward corresponding countermeasures to promote the development of Jinjiang sportswear brand.
\end{abstract}

Keywords-green marketing; Jinjiang; sportswear; consumer behavior

\section{INTRODUCTION}

Green marketing is a marketing mode aiming at meeting the common interests of consumers and operators and protecting the ecological environment. With the integration of China's economy and the world, more and more apparel enterprises are aware of the importance of green marketing, especially sportswear brands with science, technology and environmental protection as the core. If the green value of Chinese clothing is not improved, it will not meet the international market standards, and may even be excluded from the international market, resulting in a decline in the share of Chinese clothing in the international market [1]. In the further development of Jinjiang sportswear brand, the marketing means have gradually begun to try green marketing mode from the traditional marketing mode.

\section{GREEN CONSUMPTION BEHAVIOR}

Although the concept of green consumption was put forward as early as the 1970s, up to now, little research has been done on the consumption behavior of green sportswear. The international view is that green consumption needs to conform to the "5R" principles, that is, saving resources and reducing pollution; green life, environmental protection, shopping; reuse, multiple use; classified recycling, recycling; protection of nature, all things coexist [38]. Yang Xiaojing mainly used the consumption consciousness, psychology and behavior of green clothing to study the consumption behavior of green clothing [15]. Wu Jingxin's research on consumers' purchasing intention of green clothing was based on six latitudes: perceived sacrifice, green value, emotional value, functional value, social value and aesthetic value. The research on consumption behavior of green sportswear is mainly to provide suggestions and opinions on marketing for enterprises, so the research on the factors affecting consumption behavior of green marketing should be the focus.

\section{INVESTIGATION AND ANALYSIS OF COLLEGE STUDENTS' CONSUMPTION BEHAVIOR OF JINJIANG SPORTSWEAR BRAND}

\section{A. Investigation Background}

With the increasing scarcity of the earth's resources, rising prices of raw materials and rising costs, consumers' needs of health and safety are also rising. Under the impact of e-commerce, the transformation of traditional clothing industry is urgent. Green marketing is the right way for sportswear enterprises.

\section{B. Investigation Methods}

In the survey, 321 questionnaires were distributed and 300 valid questionnaires were recovered by the combination of online delivery and field release. There were 51 questionnaires in total. According to the basic information survey of the respondents, sportswear brand consumption behavior, green consumption psychology and $4 \mathrm{P}$ factors affecting consumption behavior, the contents of the survey are as follows.

\section{Survey Results and Analysis}

\section{1) Basic information}

Of the 300 college students surveyed, 96 (32\%) were boys and $204(68 \%)$ were girls, which was in line with the consumption ratio between men and women. There were 18 freshmen, accounting for $6 \%$; 26 sophomores, accounting for $8.67 \%$; 73 juniors, accounting for 24.33\%; 126 senior students, accounting for $42 \%$; 57 postgraduates and above, 
accounting for $19 \%$. Nearly half of the respondents (49.33\%) said that they purchased sportswear according to their needs. The frequency of purchasing sportswear once a month, once a quarter and once a half a year accounted for $6 \%, 32.67 \%$ and $12 \%$ respectively. It shows that college students' consumption of sports clothing is influenced by their economic strength.

The most popular sports for college students are running $(56.67 \%)$, badminton $(40.67 \%)$, bicycle $(33.33 \%)$, yoga $(31.33 \%)$ and basketball $(21.33 \%)$. Compared with other sports, these five sports have certain marketing advantages.

The result of the investigation on Jinjiang sportswear brand can be found

Under the same conditions, college students are more willing to buy Nike (48\%), Adidas (46.67\%) and other international well-known brands. The proportions of Li-Ning (24.67\%), Anta (25.33\%), Xtep (20.67), and Jordan (15.33\%) are similar. The proportions of 361 degrees $(9.33 \%)$, Guirenniao (6\%), Erke (5.33\%) and Peak (2.67\%) are relatively low. It can be seen that there is still a certain gap between domestic sportswear brands and internationally renowned sportswear brands.

The main influencing factors of college students' consumers for sportswear purchase are quality (62\%), comfort (62\%), practicability (42.67\%), cost performance $(38.67 \%)$, style $(36.67 \%)$ and brand influence $(33.33 \%)$, and whether the fabric is environmentally friendly (22\%), whether the service is good $(10.67 \%)$, whether the packaging is environmentally friendly $(4 \%)$ and beautiful $(4 \%)$, whether corporate social responsibility is strong $(3.33 \%)$ have relatively little influence. Therefore, because of the lack of economic independence, college students still pay more attention to the attributes of sportswear when choosing and purchasing them, and their concept of environmental protection needs to be strengthened.

The gaps between domestic sportswear brands and international well-known sportswear brands are mainly in brand influence $(68.63 \%)$, style design $(64.71 \%)$, product quality $(53.92 \%)$, and logo design $(47.06 \%)$, as shown in "Fig.1". Therefore, improving the brand influence and quality of sportswear is still the most important step.

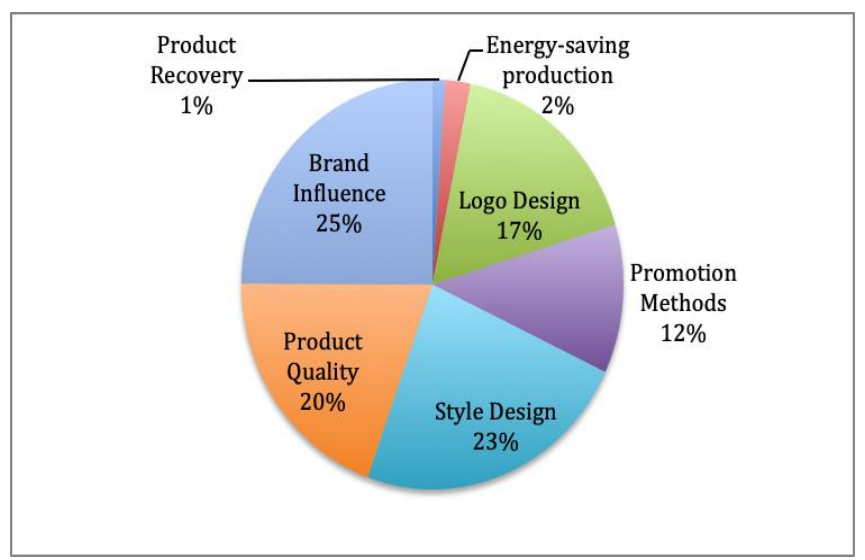

Fig. 1. Gaps between domestic sportswear brands and international sportswear brands.
2) Investigation on green consumption psychology and consumption behavior

a) Knowledge of green clothing: As shown in the "Fig. 2", the familiar labels of College Students' consumers are recyclable labels and $3 \mathrm{C}$ certification labels, accounting for $64 \%$ and $38 \%$ respectively. The labels of China's environmental protection product certification, national inspection-free products and China's energy-saving certification are slightly unfamiliar, accounting for $28 \%$, $23.33 \%$ and $23.33 \%$, it can be seen that the recognition of environmental protection labels by college students' need to be strengthened. Jinjiang sportswear brand enterprises that implement green marketing should increase the propaganda of green sportswear in order to stimulate their attention to green sportswear and green logo.

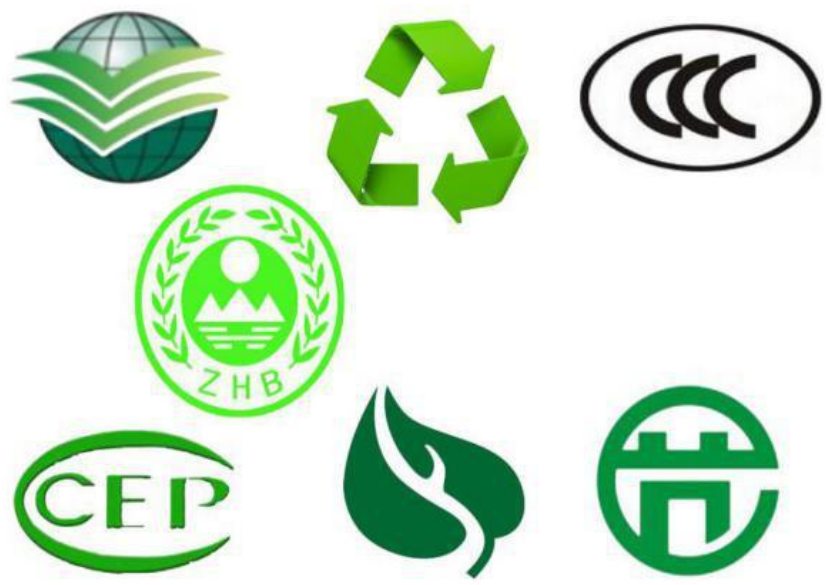

Fig. 2. Environmental protection label map of the set topics.

As shown in the "Table I", through defining "I pay more attention to the environmental protection labels of sportswear" as A1, it was found that the average value of observation variables of green clothing knowledge was less than 5, which indicated that students knew little about green clothing knowledge, and the standard deviation was more than 1, indicating that the respondents' choices of subjects were quite different.

TABLE I. Statistical TABle OF ENVIROMENTAL PROTECCTION LABELS

\begin{tabular}{|l|c|c|c|c|c|c|c|}
\hline $\begin{array}{l}\text { Observed } \\
\text { Variables }\end{array}$ & $\mathbf{1}$ & $\mathbf{2}$ & $\mathbf{3}$ & $\mathbf{4}$ & $\mathbf{5}$ & $\begin{array}{c}\text { Average } \\
\text { Value }\end{array}$ & $\begin{array}{l}\text { Standard } \\
\text { Deviation }\end{array}$ \\
\hline A1 & 4 & 4 & 60 & 92 & 140 & 4.20 & 1.85 \\
\hline
\end{tabular}

b) Product of green clothing: From "Fig. 3", it can be seen that sportswear accounted for the highest proportion in the survey of green marketing acceptance of clothing types, accounting for $31 \%$; children's clothing, maternity clothing, casual clothing and women's clothing followed, respectively, $15 \%, 13 \%, 13 \%, 12 \%$, indicating that the green marketing of sportswear is the best, Jinjiang sportswear enterprises should give full play to their advantages to meet the environmental protection needs of society, enterprises and consumers. 


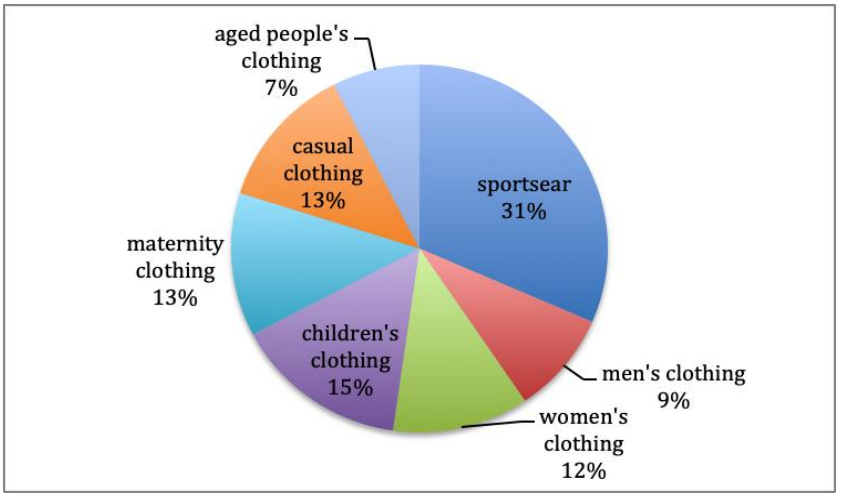

Fig. 3. Recognition of green marketing for clothing categories.

College students pay more attention to the green marketing of sportswear enterprises in terms of raw materials (76\%), design $(53.33 \%)$, packaging $(41.33 \%)$ and function $(40.67 \%)$, mainly showing the related attributes of green sportswear.

As shown in the "Table II", through defining "I support the adoption of new environmental protection fabrics for sportswear" as B1, college students tend to choose organic cotton, bamboo fiber, RPET, Viscose and other environmental protection fabrics when choosing sportswear, while China's cotton, wool, natural fibers and other raw materials production have been ranked among the world's top, Jinjiang sportswear brand enterprises can make full use of their own advantages in raw materials. Through defining "Colors and styles have a great influence on my purchasing of green sportswear" as B2, "Fabric and workmanship have a great influence on my purchase of green sportswear" as B3, it can be found that green clothing marketing is still inseparable from the product.

TABLE II. Statistical Table of Product of Green Sportswear

\begin{tabular}{|c|c|c|c|c|c|c|c|}
\hline $\begin{array}{c}\text { Observed } \\
\text { Variables }\end{array}$ & $\mathbf{1}$ & $\mathbf{2}$ & $\mathbf{3}$ & $\mathbf{4}$ & $\mathbf{5}$ & $\begin{array}{c}\text { Average } \\
\text { Value }\end{array}$ & $\begin{array}{c}\text { Standard } \\
\text { Deviation }\end{array}$ \\
\hline B1 & 2 & 2 & 26 & 86 & 184 & 4.49 & 2.05 \\
\hline B2 & 2 & 2 & 44 & 82 & 170 & 4.39 & 1.98 \\
\hline B3 & 4 & 1 & 33 & 93 & 169 & 4.41 & 2.00 \\
\hline
\end{tabular}

About the shopping bags of sportswear, tested people chose canvas $(43 \%)$, paper bags $(39 \%)$, own bags $(9 \%)$, plastic bags $(6 \%)$ and nylon bags (3\%). Therefore, sportswear enterprises can prepare more environmentally friendly shopping bags.

About the disposal of old clothing, tested people chose donation $(71.33 \%)$, recycling $(26 \%)$, selling for second-hand $(20 \%)$ and accumulating them in the family $(2 \%)$. About the way of recycling old clothing, tested people chose free recycling $(40 \%)$, indifference $(31 \%)$ and paid recycling $(29 \%)$. About the paid recycling, people chose exchanging old clothes for new ones (41\%), exchanging gifts (36\%) and selling for cash $(23 \%)$.

As shown in the "Table III", through defining "I support enterprises to recycle old clothing" as C1, "I would like to buy recyclable or reused clothing" as $\mathrm{C} 2$, it can be found that college students support the recycling strategy of old clothing, but the average score on purchasing recycled sportswear is less than 4 , which is due to quality and health concerns, as college students lack trust in the enterprises.

TABLE III. Statistical TABle OF AtTitudes of Old CLOTHING

\begin{tabular}{|c|c|c|c|c|c|l|l|}
\hline $\begin{array}{c}\text { Observed } \\
\text { Variables }\end{array}$ & $\mathbf{1}$ & $\mathbf{2}$ & $\mathbf{3}$ & $\mathbf{4}$ & $\mathbf{5}$ & $\begin{array}{c}\text { Average } \\
\text { Value }\end{array}$ & $\begin{array}{c}\text { Standard } \\
\text { Deviation }\end{array}$ \\
\hline $\boldsymbol{C} \boldsymbol{1}$ & 2 & 2 & 45 & 108 & 143 & 4.29 & 1.91 \\
\hline $\boldsymbol{C} \boldsymbol{2}$ & 5 & 4 & 128 & 103 & 60 & 3.7 & 1.58 \\
\hline
\end{tabular}

c) Promotion of Green Clothing: As shown in the "Fig. 4", establishment of green sales counters (23\%) and increasing advertising campaigns (21\%) both have high support rate. Enterprises can increase relevant publicity promotion.

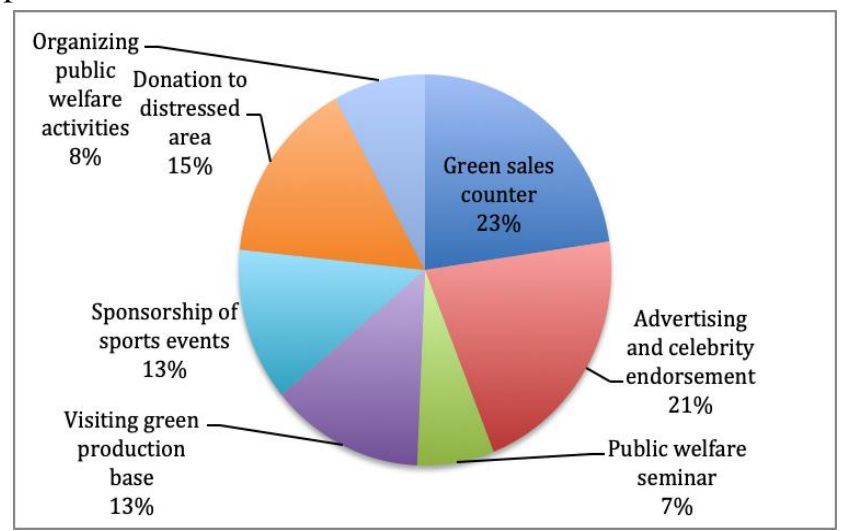

Fig. 4. Promotion of green clothing.

As shown in the "Table IV", through defining "I think the promotion of green sportswear is very important." as D1, "I would like to buy green sportswear for persuasion" as D2, "I would advise friends and relatives to buy green sportswear" as D3, "Corporate social responsibility affects my purchasing desire" as D4, college students have a positive reaction to the promotion of green sportswear, and accept enterprises with a strong sense of environmental responsibility. But it is relatively passive in promoting green products to friends; the average score is less than 4 . Because of the limited promotion of green products, consumers do not have enough trust in products; enterprises need to strengthen the promotion of relevant brands.

TABLE IV. StatisticAl TABLE OF PROMOTION OF GREEN SPORTSWEAR

\begin{tabular}{|c|c|c|c|c|c|c|c|}
\hline $\begin{array}{c}\text { Observed } \\
\text { Variables }\end{array}$ & $\mathbf{1}$ & $\mathbf{2}$ & $\mathbf{3}$ & $\mathbf{4}$ & $\mathbf{5}$ & $\begin{array}{c}\text { Average } \\
\text { Value }\end{array}$ & $\begin{array}{c}\text { Standard } \\
\text { Deviation }\end{array}$ \\
\hline D1 & 2 & 6 & 24 & 87 & 181 & 4.46 & 2.03 \\
\hline D2 & 8 & 12 & 78 & 102 & 100 & 3.91 & 1.68 \\
\hline D3 & 5 & 4 & 70 & 114 & 107 & 4.05 & 1.76 \\
\hline D4 & 2 & 3 & 72 & 106 & 117 & 4.11 & 1.80 \\
\hline
\end{tabular}


d) Price of Green Clothing: According to the "Fig. 5", most students accept that the price of green sportswear is $5 \%-15 \%$ higher than that of common sportswear. It shows that college students can accept green sportswear with little premium, but the price increase should be controlled within a reasonable range.

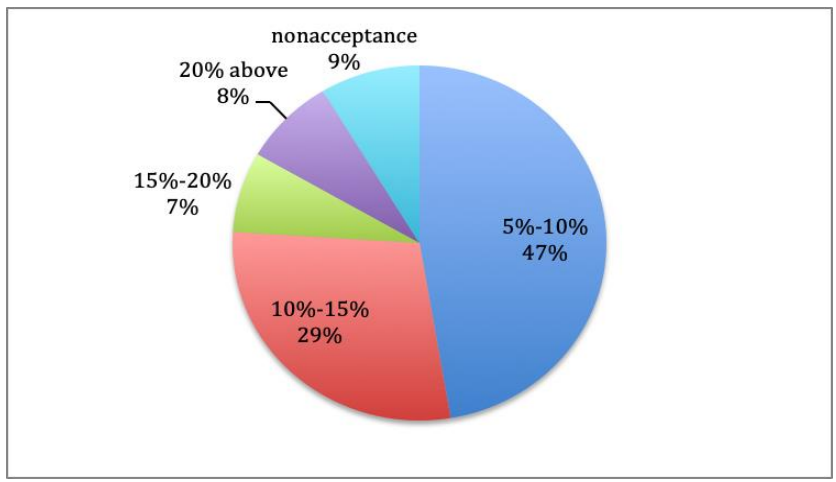

Fig. 5. Premium Acceptance of Freen Sportswear.

e) Place of Green Clothing: Among the choices of green sportswear sales place, 136 people and 102 people chose physical special stores and online flagship stores, accounting for $45 \%$ and $34 \%$ respectively, while only $16 \%$, $4 \%$ and $2 \%$ of the market stores, street retail stores and all of them. Therefore, enterprises need to pay attention to the operation of special stores and online flagship stores. These sales places of green clothing can bring consumers professionalism and enhance brand image.

As shown in the "Table V", through defining "Store decoration and display affect my desire to buy" as E1, good display can attract consumers to enter the store at the first time. The display itself conveys brand spirit and brand culture.

TABLE V. StATISTICAL TABLE OF Display OF GREEN SPORTSWEAR

\begin{tabular}{|c|c|c|c|c|c|c|c|}
\hline $\begin{array}{c}\text { Observed } \\
\text { Variables }\end{array}$ & $\mathbf{1}$ & $\mathbf{2}$ & $\mathbf{3}$ & $\mathbf{4}$ & $\mathbf{5}$ & $\begin{array}{c}\text { Average } \\
\text { Value }\end{array}$ & $\begin{array}{c}\text { Standard } \\
\text { Deviation }\end{array}$ \\
\hline $\boldsymbol{E} \mathbf{1}$ & 1 & 4 & 45 & 102 & 148 & 4.31 & 1.93 \\
\hline
\end{tabular}

Among the shop decoration and display style options, 178 people chose simple fashion style and 80 people chose simple sports style, accounting for $59 \%$ and $27 \%$ respectively. College students' demand for green sportswear brand is fashionable and simple. Shop decoration style that conforms to consumer psychology can also attract them.

\section{CONCLUSION}

Contrasting international sportswear brands, the brand recognition and product quality of Jinjiang sportswear brands still need to be improved. College students have a strong sense of responsibility for environmental protection and a strong willingness to consume green sportswear, but their knowledge of green clothing is still weak. Jinjiang sportswear brands can further enhance the brand's popularity by enhancing the product's environmental protection characteristics, increasing green promotional activities, adjusting the price appropriately, and creating fashionable and simple green decoration stores.

Green sportswear brands can form a relationship between consumer psychology and consumer behavior. Consumers rely on environmental responsibility and perceived behavior to form effective psychology. Marketers can stimulate their purchasing desire, and further enhance environmental protection knowledge and green consumption behavior. They also publicize and popularize the green life concept and environmental protection knowledge for consumers.

\section{ACKNOWLEDGMENT}

The department of Science and Technology of Fujian Province supported this research: Eco-innovation of textile and garment industry cluster of Fujian Province under the background of low carbon economy (2018R0075).

\section{REFERENCES}

[1] Zhang Danqing. Research on College Students' Clothing Consumption Behavior based on Green Marketing, Master's degree thesis of Zhejiang Sci-Tech University, 2016, pp.2.

[2] Fen Liang. Establishing cientific Development Concept and Advocating Green Consumption, Chinese Population, Resources and Environment, 2004, pp. 133-134.

[3] Yang Xiaojing. Marketing Strategy of Green Textile and Garment, Hebei Industrial Science and Technology, 2012, pp. 195-198.

[4] Wu Jingxin. Research on Consumer's Perceived Value Dimension of Green Clothing, Master's degree thesis of Beijing Institute of Fashion Technology, 2010, pp.8-9. 